\title{
The Pattern of Hematological Malignancies at Al-Gamhouria Teaching Hospital, Aden, Yemen, from 2008 to 2010
}

\author{
Yemen, Aden'de Al-Gamhouria Eğitim Hastanesinde 2008 ile 2010 \\ Arasında Hematolojik Malignansiler Paterni
}

\author{
Gamal Abdul HAMID
}

Al-Gamhouria Teaching Hospital, Department of Hematology-Oncology, Aden, Yemen

\begin{abstract}
Objective: The aim of this study was to determine the pattern of hematological malignancies at Al-Gamhouria Teaching Hospital from 2008 to 2010.

Material and Methods: Hematological malignancies diagnosed at Al-Gamhouria Teaching Hospital, Department of Hematology-Oncology from January 2008 to December 2010 based on available hematological laboratory methods and histological examination were retrospectively analyzed. Clinical diagnoses were based on history and physical examination. Complete blood count was performed in all patients, bone marrow aspiration was performed in leukemia and multiple myeloma patients, and histopathological examination was performed in cases of malignant lymphoma.
\end{abstract}

Results: Malignant hematological disorders were diagnosed in 300 patients aged 18-80 years (mean age: 43.6 years) with a male:female ratio of 1.23:1. Among the male patients the most common malignant disorder was non-Hodgkin's lymphoma, followed by Hodgkin's lymphoma and acute myeloid leukemia. Among the female patients the most common malignant disorder was non-Hodgkin's lymphoma, followed by acute myeloid leukemia, and Hodgkin's lymphoma. The study provides the frequencies for the main hematological disorders and present the different subtypes of the Hodgkin's and non-Hodgkin's lymphomas.

Conclusion: The most common hematological malignancies in male patients were Non-Hodgkin's lymphomas followed by Hodgkin's lymphoma and acute myeloid leukemia. Gender distribution showed male predominance with striking predominance in Hodgkin's lymphomas (M:F Ratio of 1.9:1).

Key Words: Malignancies, Lymphoma, Leukemia, Multiple myeloma, Aden Yemen

Özet

Amaç: Bu çalışmanın amacı Al-Gamhouria Eğitim Hastanesinde 2008 ile 2010 arasında hematolojik malignansiler paternini belirlemekti.

Gereç ve Yöntemler: Al-Gamhouria Eğitim Hastanesinin Hematoloji-Onkoloji bölümünde Ocak 2008 ile Aralık 2010 ylları arasında mevcut hematolojik laboratuvar yöntemleri ve histolojik inceleme temelinde tanı konan hematolojik

Address for Correspondence: Gamal Abdul HAMID, M.D.,

Al-Gamhouria Teaching Hospital, Department of Hematology-Oncology, Aden, Yemen

Phone: +00967-711323798 E-mail: drgamal2000@yahoo.com

Received/Gelis tarihi : September 30, 2011

Accepted/Kabul tarihi : March 29, 2012 
malignansiler retrospektif olarak analiz edildi. Klinik tanılar öykü ve fiziksel incelemeyi temel aldı. Tüm hastalarda tam kan sayımı yapıldı, lösemi ve multipl myelom hastalarında kemik iliği aspirasyonu yapıldı ve malign lenfoma vakalarında histopatolojik inceleme yapıldı.

Bulgular: 18-80 yaşlar arasındaki (ortalama yaş: 43,6 yaş) ve 1,23:1 erkek:kadın oranına sahip 300 hastada malign hematolojik bozukluklar saptandı. Erkek hastalar arasında en sık görülen malign bozukluk non-Hodgkin lenfoma ve sonrasında Hodgkin lenfoma ve akut myeloid lösemiydi. Kadın hastalar arasında en sık görülen malign bozukluk nonHodgkin lenfoma ve sonrasında akut myeloid lösemi ve Hodgkin lenfomaydi. Bu çalışma ana hematolojik bozuklukların sıklıklarını vermekte ve Hodgkin ve non-Hodgkin lenfomaların farklı alt tiplerini sunmaktadır.

Sonuç: En sık görülen hematolojik malignansiler non-Hodgkin lenfoma ve sonrasında Hodgkin lenfoma ve akut myeloid lösemiydi. Cinsiyet dağılımı erkek predominansı gösterdi ve bu durum Hodgkin lenfomalarda özellikle belirgindi (E:K Oranı 1,9:1).

\section{Anahtar Sözcükler: Malignansiler, Lenfoma, Lösemi, Multipl myelom, Aden Yemen}

\section{Introduction}

The pattern of hematological malignancies (HMs) in developing countries and developed countries differs. Among the different types of cancers, leukemia, lymphoma, and multiple myeloma appear to have greatly increased in frequency over the last 10 years. These malignancies are induced by genetic damage or mutation in somatic cells, which can result from environmental exposure to chemicals, ionizing radiation, and viral agents. Comparison of the incidence of HMs across geographic regions and time is complicated by the existence of different disease classification systems, and diagnostic criteria that vary by country, and even between hospitals and cancer registries (CRs) within a country[1].

Leukemia is a malignant neoplasm of hematopoietic stem cells characterized by diffuse replacement of bone marrow or peripheral blood by neoplastic cells; its etiology is obscure[2]. Leukemia typing is based on how quickly the disease develops and progresses. Leukemia is either chronic or acute. Furthermore, leukemia typing is also based on the type of white blood cell that is affected. There are 4 common types of leukemia: acute myeloid leukemia (AML), acute lymphoblastic leukemia (ALL), chronic myeloid leukemia (CML), and chronic lymphocytic leukemia (CLL) [3,4]. Most acute leukemias are classified as lymphoid or myeloid lineages via standard microscopic morphology, cytochemistry, and immunophenotyping [5] . Previous studies have shown that there are important differences in the incidence of the various leukemia subtypes according to geography, race/ethnicity, age, and trend pattern, indicating that the subtypes may have different etiological factors and that comprehensive global assessment of leukemia patterns is warranted[6,7].

Lymphomas are a heterogenous group of diseases with differences in epidemiology, histology, and prognosis. The incidence of Hodgkin's lymphoma (HL) and nonHodgkin's lymphoma (NHL) is higher among males than females. Malignant lymphoma is the most common malignant tumor in southeastern Yemen, has a high incidence (12.1\%) in both genders, and is the most common type of cancer in males (M:F 1.6:1)[8].

Multiple myeloma (MM) is included in the spectrum of diseases ranging from monoclonal gammopathy of unknown significance (MGUS) to plasma cell leukemia. Plasma cell proliferation usually results in extensive skeletal destruction, with osteolytic lesions, hypercalcemia, anemia, and occasionally plasma cell infiltration in different organs. Excessive production of a monoclonal (M) protein can lead to renal failure, hyperviscosity syndrome, or recurrent bacterial infections[9]. The annual incidence of MM in the US is 3-4/100,000 and accounts for 1\% of all cancers diagnosed in the US and MM accounts for approximately $10 \%$ of all hematological malignancies and $20 \%$ of all hematological malignancies in African Americans. Median age at onset of MM in US is 71 years[10].

The aim of the present study was to determine the distribution and pattern of various HMs diagnosed at Al-Gamhouria Teaching Hospital, Aden, Yemen, and to compare them to those reported in other studies, so as to improve their diagnosis and treatment at our hospital.

\section{Patients and Methods}

All patients with HMs that were referred to, diagnosed, and managed at Al-Gamhouria Teaching Hospital (GTH), Department of Hematology-Oncology, Aden, Yemen, between 1 January 2008 and 30 December 2010 were included in the study. The Republic of Yemen has a population of approximately 22 million. GTH is one of the largest public hospitals in Yemen; it has 500 beds and pro- 
vides services to more than 60,000 hospitalized patients and more than 600,000 outpatients annually.

Demographic data, including age and gender, and a detailed medical history were recorded for each patient. Each patient then underwent a detailed clinical examination, with particular emphasis on hematological parameters. Diagnoses were based on clinical features, blood counts, and peripheral blood films, and were confirmed via bone marrow cytology (Cytochemistry ;Myeloperoxidase and Periodic Acid Schiff) were used when indicated. Diagnosis of lymphoma was based primarily on documented histological reports. Other investigations performed for diagnosis or management included X-ray, creatinine, liver function, serum protein electrophoresis, serum total proteins, and albumin. Blood film examination for cell morphology was performed using Leishman's stain. Bone marrow was examined following aspiration of the poste- rior iliac spine, as described by Dacie and Lewis[11]. The study protocol was approved by the Al-Gamhouria Teaching Hospital Ethics Committee.

\section{Results}

In total, 300 patients aged between $18-80$ years (mean age: 43.6 years) with a male:female ratio of $1.23: 1$ were diagnosed with malignant hematological disorders.

In table 1 NHL was the most common HM (37.66\%), followed by HL (21.0\%), AML (15.66 \%), and ALL (7.66\%). Among the chronic leukemia's, CML was more common than CLL (9.33\% and $4.66 \%$, respectively). In all, 12 patients had MM (4.0\%). The 1-year relative survival rate was $87 \%$ in the HL patients, $75 \%$ in the CML patients, $72 \%$ in the CLL patients, $71 \%$ in the NHL patients, $35 \%$ in the ALL patients, and $18 \%$ in the AML patients. Table 2 shows that most of the patients with AML (29.7\%) were

Table 1: Distribution of HMs according to type of malignancy, gender, mean age, and survival.

\begin{tabular}{|c|c|c|c|c|c|c|}
\multirow{2}{*}{ Type of malignancy } & \multicolumn{2}{|c|}{$\mathrm{n}$} & \multicolumn{2}{c|}{ Total } & $\begin{array}{c}\text { 1-Year Relative } \\
\text { Survival }\end{array}$ \\
\cline { 2 - 7 } & Male & Female & $\mathrm{n}$ & $\%$ & Mean age (years) & $71 \%$ \\
\hline NHL & 60 & 53 & 113 & 37.66 & 50 & $87 \%$ \\
\hline HL & 41 & 22 & 63 & 21.00 & 34 & $18 \%$ \\
\hline ALL & 22 & 25 & 47 & 15.66 & 35 & $35 \%$ \\
\hline CML & 14 & 9 & 23 & 7.66 & 24 & $75 \%$ \\
\hline CLL & 14 & 14 & 28 & 9.33 & 45 & $72 \%$ \\
\hline Total & 7 & 6 & 14 & 4.66 & 57.5 & $58 \%$ \\
\hline
\end{tabular}

NHL: non-Hodgkin's lymphoma HL: Hodgkin's lymphoma AML: Acute myeloid leukemia ALL: Acute lymphoblastic leukemia CML: Chronic myeloid leukemia CLL: Chronic lymphatic leukemia MM: Multiple myeloma

Table 2: Distribution of HMs according to age.

\begin{tabular}{|c|c|c|c|c|c|c|c|c|c|}
\hline \multirow{2}{*}{$\begin{array}{l}\text { Age groups } \\
\text { (years) }\end{array}$} & & & & & & & & \multicolumn{2}{|c|}{ Total } \\
\hline & $\begin{array}{c}\text { AML } \\
\text { n/\% }\end{array}$ & $\begin{array}{l}\text { ALL } \\
\mathrm{n} / \%\end{array}$ & $\begin{array}{l}\text { CML } \\
\text { n/\% }\end{array}$ & $\begin{array}{l}\text { CLL } \\
\mathrm{n} / \%\end{array}$ & $\begin{array}{c}\text { NHL } \\
\mathrm{n} / \%\end{array}$ & $\begin{array}{l}\mathrm{HL} \\
\mathrm{n} / \%\end{array}$ & $\begin{array}{l}\mathrm{MM} \\
\mathrm{n} / \%\end{array}$ & $\mathrm{n}$ & $\%$ \\
\hline $18-30$ & $14 / 29.8$ & $17 / 73.9$ & $7 / 25$ & 0 & $22 / 19.5$ & $37 / 58.75$ & 0 & 97 & 32.33 \\
\hline $31-40$ & 9/19.1 & $1 / 4.35$ & $6 / 21.4$ & 0 & $13 / 11.5$ & $6 / 9.5$ & 0 & 35 & 11.66 \\
\hline $41-50$ & $10 / 21.3$ & $2 / 8.7$ & $7 / 25$ & $2 / 14.3$ & $18 / 15.9$ & $8 / 12.7$ & $1 / 8.3$ & 48 & 16.00 \\
\hline $51-60$ & $8 / 17.0$ & $2 / 8.7$ & $5 / 17.9$ & $8 / 57.1$ & $28 / 24.8$ & $3 / 4.75$ & $5 / 41.6$ & 59 & 19.66 \\
\hline $61-70$ & $6 / 12.8$ & $1 / 4.35$ & $3 / 10.7$ & 321.4 & $23 / 20.3$ & 914.3 & $4 / 33.3$ & 49 & 16.33 \\
\hline $71-80$ & 0 & 0 & 0 & $1 / 7.2$ & 9/8.0 & 0 & 2.16 .6 & 12 & 4.00 \\
\hline Total & $47 / 100$ & $23 / 100$ & $28 / 100$ & $14 / 100$ & $113 / 100$ & $63 / 100$ & $12 / 100$ & 300 & 100 \\
\hline
\end{tabular}

AML: Acute myeloid leukemia ALL: Acute lymphoblastic leukemia CML: Chronic myeloid leukemia CLL: Chronic lymphatic leukemia MM: Multiple myeloma NHL: non-Hodgkin's lymphoma HL: Hodgkin's lymphoma 
aged $18-50$ years and $73.9 \%$ of the ALL patients were aged $18-30$ years. $21.4 \%$ of CML patients were aged $31-50$ years and $57.1 \%$ of CLL patients were aged $51-60$ years. NHL occurred in $24.8 \%$ patients aged $61-70$ years, followed by $20.4 \%$ of those aged $51-60$ years, whereas $58.7 \%$ of HL patients were aged $18-30$ years.

Table 3: Distribution of malignant lymphomas

\begin{tabular}{l|c|c|}
\hline HL according to Rye classification & \\
Mixed cellularity & 31 & 49.2 \\
Nodular sclerosis & 18 & 26.6 \\
Lymphocyte predominance & 8 & 12.7 \\
Lymphocyte depletion & 6 & 09.5 \\
Total & $\mathbf{6 3}$ & $\mathbf{1 0 0}$ \\
\hline NHL according to working formulation \\
\hline NHL & $\mathbf{n}$ & $\%$ \\
\hline Low grade & 18 & 15.9 \\
Intermediate grade & 69 & 61.1 \\
High grade & 18 & 15.9 \\
Miscellaneous & 8 & 07.1 \\
Total & $\mathbf{1 1 3}$ & $\mathbf{1 0 0}$
\end{tabular}

Table 4: Histological types of non-Hodgkin's lymphoma.

\begin{tabular}{l|c|c|} 
Histological type & n (\%) & Mean age \\
Small lymphocyte & $4(3.5)$ & 59 \\
Follicular small cleaved cell & $7(6.2)$ & 63 \\
Follicular mixed & $7(6.2)$ & 52 \\
Follicular large & $2(1.8)$ & 67 \\
Diffuse small cleaved cell & $9(8.0)$ & 62 \\
Diffuse mixed & $11(9.7)$ & 47 \\
Diffuse large cell & $47(41.6)$ & 46 \\
Immunoblastic & $2(1.8)$ & 24 \\
Lymphoblastic & $12(10.6)$ & 28 \\
Burkitt's? & $4(3.5)$ & 36 \\
Others & $8(7.0)$ & 47 \\
Total & $113(100)$ & 51.4
\end{tabular}

According to Rye classification, [12] the most frequent type of HL was mixed cellularity (49.2\%), followed by nodular sclerosis (26.6\%), and lymphocyte depletion (9.5\%) (Table 3). According to a working formulation for clinical usage, there are 3 major prognostic grades for HL: intermediate $(n=69$ [61.1\%]; low grade $(n=18$ [15.9\%]); high grade $(\mathrm{n}=18$ [15.9\%]). The growth pattern was diffuse in $67(59.3 \%)$ patients and follicular in $16(14.16 \%)$ patients (Table 4). Among the various histological subtypes, 47 (41.6\%) patients had diffuse large cell lymphoma and 12 (10.6\%) patients had lymphoblastic lymphoma.

\section{Discussion}

Lymphoma and leukemia are common in Yemen (24.8\%) [8,13,14]. Malignant lymphoma constituted $58.7 \%$ of all diagnosed HMs in the present study; this high prevalence rate is in agreement with earlier reports from Yemen and the US[13,15]. In the present study $23.3 \%$ of the patients had acute leukemias (AML and ALL), whereas CML was the fifth most common HM, accounted for 9.3\% of patients and CLL accounted for $4.7 \%$. In contrast, in Western countries CML accounts for $20 \%$ of leukemia subtypes and CLL accounts for 25\%[16].Similar results have been reported by Al-Ghazaly from Sana'a, Yemen[14] and by Noor et al. from Kenya, [17] whereas ALL was reported to be the most common HM in Karachi,[18] which indicates the geographic variability of the incidence of acute leukemia.

The incidence of lymphoma is increasing worldwide, largely due to NHL.[19-21] According to available data on cancer in southeastern Yemen (1983-1989), malignant lymphoma was the $2^{\text {nd }}$ most common malignancy; among males it ranked $2^{\text {nd }}$ and among females it ranked the $5^{\text {th }}$. [13] Data from developed countries indicate a male:female ratio of 1.4:1, whereas in developing countries the ratio ranges from 4.5:1 to 3.1:1. In general, many more HMs have been reported to occur in males than in females; [22] However, in the present study the number of males and females with CML and CLL was equal, and a slightly higher number of females than males had AML. In the present study the male:female ratio for HL and ALL was

Table 5: Lymphoma and leukemia age-standardized incidence rates in Yemen, Egypt, Jordan, and the US [25-26].

\begin{tabular}{|c|c|c|c|c|c|} 
& $\begin{array}{c}\text { Yemen, } \\
\text { 2002-2006 }\end{array}$ & $\begin{array}{c}\text { Egypt, } \\
\text { 1999- 2001 }\end{array}$ & $\begin{array}{c}\text { Jordan, } \\
1996-2001\end{array}$ & $\begin{array}{c}\text { Saudi Arabia, } \\
2004\end{array}$ & $\begin{array}{c}\text { The US, } \\
1999-2001\end{array}$ \\
\hline NHL & 4.2 & 16.3 & 6.4 & 4.1 & 12.9 \\
HL & 2 & 2.1 & 2.5 & 2.1 & 2.4 \\
\hline Leukemia & 5.6 & 6.0 & 6.3 & 2.7 & 8.8 \\
\hline
\end{tabular}


$1.9: 1$ and $1.6: 1$, respectively, which is the opposite of that previously reported.[23-24]

The age-standardized incidence rate for leukemia (Table 5) is $8.8 \%$ in the US, $6.3 \%$ in Jordan, $5.4 \%$ in Egypt, $4.2 \%$ in Yemen, and 3.9\% in Saudi Arabia.[25-26] The agestandardized incidence rate for NHL in the US is among the highest in the world. Age-standardized incidence rate (ASR) in NHL have been reported to be low (6.5\%) in East Asia, moderate (10.2\%) in Africa and the Middle East, and high in Western Europe (17.9\%), Australia( 25\%) and Canada( $27.7 \%)$. International variation is due to differences in exposure to risk factors like the agricultural use of the pesticide 1,1,1-trichloro-2,2'bis ( -chlorophenyl)ethane (DDT) and increased risk of non-Hodgkin lymphoma. [27] The incidence rate of NHL increased in in Western Europe and North America during the 1990s and has leveled off in recent years due in part to AIDS; however, NHL as a complication of AIDS does not occur in a sufficient proportion of AIDS cases to fully account for the extent of the increase. Other possible explanations for the high NHL incidence rate in Egypt may be the high prevalence of hepatitis C virus HCV infection. [28] Human papilloma Virus 8 HHV8 infection, adverse environmental exposure and pollution in those countries.

Mean survival in the present study was lower than that previously reported, $[29,30]$ and may have been due to several factors, including late presentation to hospital or a shortage of chemotherapeutic drugs. Improve outcome was reported for patients with early presentation and early stages of disease.

In the present study $45 \%$ of the patients with NHL and $53.7 \%$ of $\mathrm{HL}$ were aged $51-70$ years and $18-30$ years, respectively. In other studies the majority of NHL cases were aged 40-69 years-the peak age range being 50-59 years. In reports from Western countries HL was more prevalent among young adults (16 years) and the incidence of the disease makes pik late in the third decade of life (36 years), [31] which is similar to the present findings and indicates that there isn't a significant difference in incidence rate of HL based on age. The MM patients in the present study had a median age of 60 years, which is younger than previously reported [32]. The mean age reported by Inamullah et al. also matches with our study, while the mean age reported by Dispenzieri et al. in the US was 71 years, which was higher than our results[32-33]. In our study the mean age in leukemia's agrees with previous studies in Africa[34]. The difference in the age incidence observed in this study when compared to the western countries may be due to the interplay of both environmental and racial factors. [34]
In general NHL with a follicular pattern of growth has a more favorable prognosis than NHL with a diffuse pattern-within the same cytological subtype. The growth pattern of NHL in the present study was diffuse in 59.3\% of cases and follicular in only $14.2 \%$, which is in sharp contrast to Western reports in which $30 \%-40 \%$ of all NHL cases are the follicular type[34]. In this study diffuse, mixed small and large cell lymphoma accounted for $9.7 \%$ of all the histological types, which is slightly higher than that reported from Western countries[33]. Moreover, $41.6 \%$ of NHL cases in the present study were diffuse large cell, without specification of the cell type. The frequency of Burkitt's lymphoma in the present study was with the lower than that reported in Ilorin, Nigeria but was similar study reported from Sudan[35-36].

\section{Conflict of Interest Statement}

The authors of this paper have no conflicts of interest, including specific financial interests, relationships, and/ or affiliations relevant to the subject matter or materials included.

\section{References}

1. Carli PM, Delafosse P, Duchenet V, et al. Guide de recommandations pour l'enregistrement des he'mopathies malignes par les registres de cancer. Paris, France: INVS and FRANCIM; 2005. http://www.inversussante.fr/ publications/2005/guide_hemopathies_malignes/guide_ hemopathies_malignes.pdf. Accessed March 28, 2010.

2. Dennis AC. and Mary CT. Acute leukemia. In manual of clinical oncology 6th edition London. Blackwell Science, 2009, 53-55

3. Cassidy J, Bissett D, Roy AJ, Spence OBE. Acute leukemia. In oxford university press 2010; 528-539.

4. Thachuk DC, Hieschmann JV. Leukemia. In Wintrobes atlas of clinical hematology, 1st edition Lippincott Williams 2009; 48-136.

5. Bennett JM, Catovsky D,Daniel MT, Flandrin G, Galton DA, GralnickHR, Sultan C. Proposed revised criteria for the classification of acute myeloid leukemia: A report of the French-American-British Cooperative group. Ann Intern Med 1985; 103:620-625.

6. Kulshrestha R, Sah SP. Pattern of occurrence of leukemia at a teaching hospital in eastern region of Nepal - A six year study. J Nepal Med Assoc 2009; 48(173);35-40.

7. Estey EH, Faderl SH, Kantarjian HM. Hematology malignancies: Acute leukemia. Springer $1^{\text {st }}$ edition. 2008

8. Hamid GA, Bawazir A, Tayeb MS. Malignant lymphoma in southeastern governorates of Yemen. University of Aden Journal of Natural and Applied Science, 2000; 4, 203-210. 
9. Kumar V, Abbas AK, Fausto N, Aster JC, editors . Pathologic Basis of Disease. 8th ed. Philadelphia:Saunders Elsevier 2010; 589-638.

10. Rajkumar SV, Kyle RA. Symposium on Oncology Practice: Multiple Myeloma: Diagnosis and Treatment. Mayo Clin Proc 2005; 80: 1371-1382.

11. Dacie JV and Lewis SM. Practical Haematology; Churchill Livingstone, 10 edition 2006.

12. Harris NL. Hodgkin's disease: classification and differential diagnosis. Mod Pathol 1999;12:159-175.

13. Bawazir AA, Hamid GA, Morales E. Available data on cancer in southeastern of Yemen. Eastern Mediterranean Health Journal 1998; vol 4 No 3.

14. Al-Ghazaly J. Pattern of adult leukemia at Al-Jomhori educational hospital, Sanaa, Yemen. Turk J Haematol 2005; 22: 31-35.

15. Hermandez JA, Land KJ, McKenna RW. Leukemias, myeloma and other lymphoreticular neoplasms. Cancer 1995; 75: 381-394

16. Kurt Possinger , Anne C. Regierer. Leukemia: In Haematologie Onkologie ${ }^{\text {1st }}$ ed. ELSEVIER 2007; 331-58.

17. Noor NA, Masood M. Clinico-epidemiological study of Leukemia in Multan. Pak J MedResearch 1998; 28: 232243.

18. Bashir M, Zaman S, Rafatullah, Wazir F, Shoaib M, Biland B. Hematological and clinical presentation of acute leukemias at Khyber Pukhtoonkhwa; Gomal Journal of Medical Sciences July-December 2010, Vol. 8, No. 2: 130-140

19. Parkin DM, Bray F, Ferlay J, Pisani P. Global cancer statistics, 2002. CA Cancer J Clin 2005;55:74-108.

20. Plesko I, Kramarova E, Vlasak V, Obstinikova A. Development of registration and cancer incidence rates and trends in Slovakia. Eur J Cancer 1991;27:1049-1052.

21. Rabkin CS, Biggar RJ, Horn JW. Increasing incidence of cancers associated with the human immunodeficiency virus epidemic. Int J Cancer 1991; 47:692-696.

22. Aftab K, Bhurgri Y, Pervez S. Small B cell Non-Hodgkins Lymphoma in Pakistan. J Pak Med Assoc 2006; 56:22-25.

23. Babatunde AS, Amiwero CE, Olantunji PO, Durotuve IA. Pattern of hematological malignancies in Ilorin, Nigeria: A ten year review. The internet Journal of Hematology. 2009:5

24. Omoti CE and Awoduo O. Adult leukemia in Niger delta region of Nigeria Omoti. PAk J Med Sci 2005 Vol. 21 No 3;253-257.
25. Ba Saleem HO, Bawazir AA, Moore M, Al-Sakkaf KA.Five years cancer incidence in Aden Cancer Registry, Yemen (2002-2006). Asian Pac J Cancer Prev 2010;11:507-511.

26. Salim EI, Moore MA, Al-Lawati JA, Al-Sayyad J, Bazawir A, Bener A, Corbex M, El-Saghir N, Habib OS, Maziak W, Mokhtar HC, Seif-Eldrin IA, Sobue T. Cancer epidemiology and control in the arab world - past, present and future. Asian Pac J Cancer Prev 2009;10:3-16.

27. Parkin DM, Ferlay M, Hamdi-Cherif M, Sitas F, Thomas $\mathrm{J}$, Wabinga $\mathrm{H}$ et al. Cancer in Africa: epidemiology and prevention. IARC scientific publication no. 153. Lyon (France): International Agency for Research on Cancer; 2003

28. Mueller NE, Mohar A, Evans A. Viruses other than HIV and non-Hodgkin's lymphoma. Cancer Res 1992; 52:5479. 5481.

29. Colby TV, Hoppe RT, Warnke RA. Hodgkins disease: A clinicopathological study of 659 cases. Cancer 1982; 49: 1848-1858.

30. Ferrà C, Marcos P, Misis M, Morgades M, Bordejé ML, Oriol A, Lloveras N, Sancho JM, Xicoy B, Batlle M, Klamburg J, Feliu E, Ribera JM. Outcome and prognostic factors in patients with hematologic malignancies admitted to the intensive care unit: A single-centre experience. Int J Hematol 2007; 85: 195-202.

31. Kumar V, Abbas AI Fausto N. Robbins and Cotran .Pathologic basis of disease.7th ed. Philadelphia, Pa.: Elsevier Saunders 2005

32. Inamullah, Raziq F, Tahir M, Wazir R, Rafiq A. Hmatological presentation of multiple myeloma in Khber Pakhtunkhwa. Gomal Journal of Medical Sciences . 2010, Vol. 8, No. 2, 130-133

33. Dispenzieri A, Lacy MQ, Greipp PR . Multiple Myeloma. In: Greer JP, Forester J, Lukens JN, Rodgers GM, Paraskevas F, Glader B. editors. Wintrobe's Clinical Hematology. 11th ed. Philadelphia: Lippincot Williams \& Wilkins 2004; 2583 636

34. Harrington DS, Ye YL, Weisenburger DD, Armitage JO, Pierson J, Bast M, Purtilo DT. Malignant lymphoma in Nebraska and Guangzhou, China: a comparative study. Hum Pathol 1987;18: 924-928.

35. Oladipupo Williams CK, Bamgboye EA. Estimation of incidence of human leukemia subtypes in an urban African population. Oncology 1983; 40: 381-386.

36. Ahmed MA, Omer A, el Hassn AM. Malignant lymphomas at the Pathology Department, University of Khartoum, Sudan. East Afr Med J 1984; 61: 627-631. 